\title{
IS MAJOR ANALYSIS: A FRAMEWORK FOR EVALUATING EMERGING TRENDS
}

\author{
Roger L. Hayen, Central Michigan University, roger.hayen@cmich.edu
}

\begin{abstract}
This effort examines a framework for evaluating current information systems (IS) majors. The approach is developed for application to AACSB-accredited schools and consists of a base school, a number of peer schools, and an equal number of aspirational schools. A framework for viewing information technology (IT) trends is established whereby these trends are mapped to generally accepted courses for these majors. A framework for integrating IT trends in the IS major is presented to guide the development of a suggested IS major. The confluence of the courses in the IS majors and the emerging IT trends is proposed in order to formulate a revised major that blends the trends with the courses. The framework suggests a frequency analysis for relating courses to trends. A new IS major can be drawn from the analytics of the proposed framework. Overall, application of this framework may lead to a new suggested IS major having a contemporary design with a focus on the agility to continue to accommodate new and emerging trends in IT as a means for increasing student interest in the major.
\end{abstract}

Keywords: IS curriculum, IS trends, IS major agility, IS major framework

\section{INTRODUCTION}

Information systems (IS) and its companion information technology (IT) continue to undergo dramatic changes. Some of the outstanding points reported by Paquet [18] include these facts:

1) Data centers can consume forty times more energy than the offices which they support.

2) Wikipedia, launched in 2001, averages 4,300 new articles every day. A current-generation network switch could move all 13 million articles in a mere 0.001 seconds.

3) The average American teenager sends 2,282 text messages each month.

4) If Facebook was a country, it would be the third largest in the world.

5) The computer in a cell phone today is a million times cheaper, a thousand times more powerful, and about a hundred thousand time smaller than the one computer installed at MIT in 1965 , less than fifty years ago.

Clearly, as reported by Computer Economics [2]:

IT is continually evolving. New technology solutions appear while others mature and then decline in popularity. Some new technologies show early promise and are adopted quickly; some move slowly into the mainstream; and still others become hot topics only to vanish because of poor economic experiences of the pioneering users. IT initiatives can come in and out of fashion with astonishing rapidity as vendors push the next big service or solution. Only with time can IT executives know for certain which emerging IT strategies will have staying power and which will fall short of the hype.

For these reasons, a student with an IS major must be prepared for these constant changes driven by technology advances. There is a need to continually identify and re-assess critical skills and curricula due to the rapidly changing characteristic of IT [21]. The results, of a study of the dynamics of IS/IT skill by Lee and Mirchandani [12], conclude the perception of a generic IS curriculum is now obsolete and emphasize that IS curricula should be tailored. An IS curriculum is advocated which is consistent with the trends in IS technology and the skills demanded in the labor market. Overall, they suggest that:

1) The importance, of most IS/IT skills, is continually increasing over time.

2) That wireless communications and applications, mobile commerce applications and protocols, IS security, Web applications, services, and protocols, and data management are the top five rapidly growing skills. 


\section{Issues in Information Systems}

Volume 13, Issue 2, pp. 238-247, 2012

3) That IS security, data management, project management and other business skills, Web applications, services, and protocols, and wireless communications and applications are expected to be the most important five skills in the future.

This is the environment for this consideration of a framework for an IS major within a Bachelor of Business (BB) undergraduate degree. The BB degree is contemplated within the guidelines established by the Association to Advance Collegiate Schools of Business (AACBS), also known as AACSB International. The framework methodology may be applied to any comparative set of AACSB-accredited member schools. Where one school is the base school for which a revised IS major within a BB degree is the central focus. The comparison includes a group of peer schools and an equal number of aspirational schools. A peer school is one viewed as similar to the base school, whereas and aspirational school is viewed at a higher level of recognition than the base school. The framework suggests a process for examining the IS majors of these schools relative to emerging trends. That is, with the continual changes in IS and IT, what does a IS major within a BB undergraduate degree look like in today's environment.

The inquiry is presented in the order of a degree framework which portrays the relationship of a BB degree to a IS major and a major framework which relates course categories and emerging trends with an affiliation among them. Overall, the frameworks lay out a process for an analysis that uses a data-driven approach to decision making.

\section{FRAMEWORK}

A framework is useful in understanding relationships among the components of a degree program and subsequently among the courses within the major of that degree. This provides a perspective of the marriage of the degree and a major within that degree. First, the overall degree framework is considered, and then a major framework is contemplated within that degree framework.

\section{Degree Framework}

For a BB undergraduate degree, the overall components of the degree typically include those of general education, a business core, and a major, such as the IS major (Figure 1). In this inquiry, the focus is on the IS major. That major is essentially built on top of the general education courses and the BB or BSBA core courses. The BSBA (Bachelor of Science in Business Administration) is a typical degree offered by various AACSBaccredited schools. These majors provide students with knowledge and skills that distinguish them and provide a foundation for their careers, especially in entry level positions.

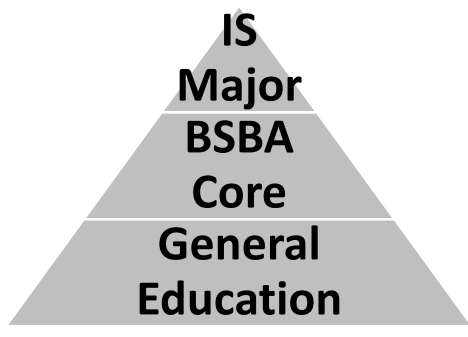

Figure 1 - Bachelor in Business overview perspective

The IS major, like other majors in a college or school of business, consists of a foundational core of required courses, elective courses, and trend courses (Figure 2). That is, the foundation or required courses serve the same role for a major as the general education courses do for a degree. Here trend courses focus on emerging industry trends that encompass the foundational courses and the electives. This is compatible with the foundational and specialization courses described by Lee and Mirchandani [12]. Within a specialization, courses may include up-to-date technologies that are reflected in emerging trends. This raises the question as to what extent emerging trends might be included within the required and elective courses relative to one or more trend courses. As evidenced by Paquet [18] and his description of the use of text messaging, undergraduate 


\section{Issues in Information Systems}

Volume 13, Issue 2, pp. 238-247, 2012

students appear to be fascinated by the latest IT advances and are often early adopters of these technology. Considering this, emerging technologies are important to undergraduate degree students. Hence, those technologies can be leveraged to increase student interest in a IS major.

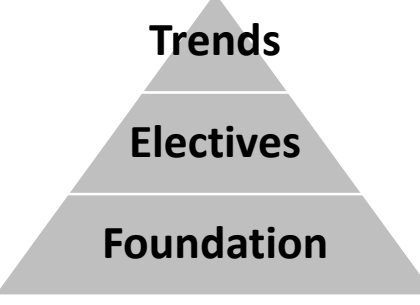

Figure 2 - IS major courses overview perspective with trend add-on

Figure 2 portrays an augmented or add-on approach to emerging IT trends. Figure 3 is another approach with an integrated perspective. That is, emerging IT trends are included as a specific learning objective within each of the foundation or required IS major courses and the elective courses for that major.

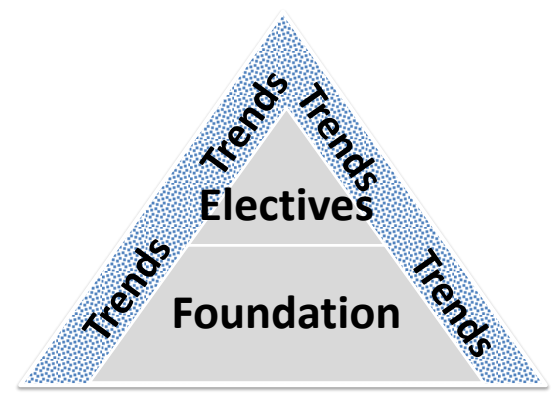

Figure 3 - IS major courses overview perspective with integrated emerging trend wrapper

One more approach is worthy of consideration. Figure 4 illustrates a blended approach to emerging IT trends integration. Here, emerging trends are included as one learning objective within the required and elective course and at the same time delivered in a separate emerging trends course. While some emerging trends can be incorporated within the required and elective courses, some topics such as the current trend for green IT or mobile devices, seem to be key new topics worthy of more in-depth study than could be included within the other required and elective courses.

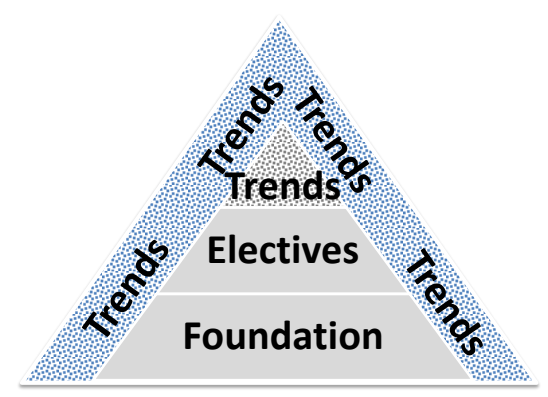

Figure 4 - IS major courses overview perspective with a blended emerging trends tactic

These degree frameworks present the three approaches of augmented, integrated, and blended. Which is the most appropriate approach? This is a question to be addressed by each individual school. An analytic framework provides a structured method for conducting an evaluation and assists with a conscious decision as to the strategy deployed. 


\section{Issues in Information Systems}

Volume 13, Issue 2, pp. 238-247, 2012

\section{Major Framework}

A framework for the major itself can be postulated using a data-driven method that utilizes secondary data sources. These include information gathered from AACSB-accredited schools in a study group of comparable schools and from a literature review conducted using many sources, including those retrieved from the Internet. All the schools in the study group should have their academic programs organized into the same duration, such as semesters. This facilitates the most direct comparison among those programs, as typically measured in credit hours. That is, study groups where schools all reference credit hours are most directly comparable. From data obtained from the study groups, the IS major course requirements are acquired for evaluating course deployment.

A description of the IS major is obtain from each of the schools in the study group. The major descriptions include a listing of the courses for the major with categories of required courses and elective courses. A database can be created to store this information. For each school's major, the courses contained within the major were entered in the database. This consists of the course name, course number, and whether it is a required or elective course. While many courses have similar names, very few have identical names. To provide a structure for comparison, judgment is applied to create a course category identifier that represents a general categorization for these courses. For example, 19 course identifications are established (Table 1). The categories should surface from the analysis of the course titles. They are not a pre-determined set of categories; rather they are extemporaneous and reflect the courses found by examination of the majors in the study group. For the elective courses, many of the course titles are likely to represent a unique offering by a school. Those courses are for a specific and identifiable content. It is just this content is limited across the schools in the study group. These may be pooled in a single "other" category for purposed of creating a data-driven framework for IS majors.

Many schools in the study group may include courses for internships, independent studies or readings, practicums, honors thesis, study abroad, and special problems with a limited number of offerings. These courses may be used to satisfy requirements for the overall undergraduate degree, for a particular degree as core courses or electives, and for a major within a degree as elective courses. These courses may be viewed as generally available courses for many undergraduate majors. With such courses, the content is variable and divergent. They do not lend themselves to a common course category classification for a BB degree or a IS major. For these reasons, such courses are best excluded from creating a fundamental framework from the study group. The result is likely a set of course categories specifically designated within typical IS majors of schools within the study group (Table 1).

Table 1 - Example Course Categories

\begin{tabular}{|l|l|}
\hline $\begin{array}{l}\text { Course } \\
\text { Category }\end{array}$ & Description \\
\hline BI & business intelligence/decision support/business analytics \\
\hline CP & computer programming \\
\hline DB & database \\
\hline EBUS & e-business \\
\hline ERP & enterprise resource planning \\
\hline ISP & information systems project \\
\hline NET & networking/communications \\
\hline OTHR & other - nec (not elsewhere classified $)$ \\
\hline PM & project management \\
\hline SAD & system analysis and design \\
\hline SEC & security \\
\hline SEMIN & seminar in current topics \\
\hline SSM & system software administration \\
\hline WEB & web development \\
\hline
\end{tabular}




\section{Issues in Information Systems}

Volume 13, Issue 2, pp. 238-247, 2012

Current emerging IT trends may be examined by using a literature search to find information on trends. Different sets of the top ten future IT trends should be scrutinized, such as those found in [1], [2], [3], [5], [9], [18], and [22]. None of these future prognostications is identical. From this, a database of the emerging IT trends may be created. Judgment can be applied to the trend descriptions to create a set of trend categories that are grouped based on their similarities. For example, a set of 18 categories may emerge from the examined sets of trend. Each trend item can then be assigned to a category for analysis (Table 2). These categories evolve from the observed trends and are not pre-determined. This makes this evaluation framework a repeatable method as trends change with evolving technology.

When carrying out the literature search for the emerging IT trends, a number of references are likely to be found that described one or a few trends. These are not sufficient for identifying sets of ten future IT trends preferred for the analysis in this study. On the other hand, they are useful in measuring the frequency of emerging trends. These collateral trend references are defined as Trend Support Research and included in Table 2 to corroborate the frequency of the categories contained under the Trend Code. This data is used in the analysis of trends for course candidates within a suggested revised IS major.

Table 2 - Trend Categories

\begin{tabular}{|l|l|l|}
\hline $\begin{array}{l}\text { Trend } \\
\text { Code }\end{array}$ & Description & $\begin{array}{l}\text { Trend Support } \\
\text { Research }\end{array}$ \\
\hline Big Data & Big data - the elephant in the room & \\
\hline Big Vend & $\begin{array}{l}\text { There's no go-to cloud platform provider, so the vendor wars will } \\
\text { heat up this year }\end{array}$ & \\
\hline BusInt & Next-generation analytics & \\
\hline Cloud & Cloud computing & {$[13],[16]$} \\
\hline Coll & Collaboration technologies & \\
\hline Comm & Unified communications - extended & \\
\hline CRM & Renewed focus on customer experience & \\
\hline DocMgt & Document management & \\
\hline ERP & SAP will reemerge & {$[6],[8]$} \\
\hline Fabric & Converged fabrics & {$[11],[15]$} \\
\hline Green IT & Energy efficiency and monitoring & \\
\hline Legacy & Legacy migrations - your users & {$[7],[11]$} \\
\hline Mobil & Mobile devices & {$[11],[22]$} \\
\hline SaaS & Smarter software & {$[10],[14]$} \\
\hline Security & Security technologies & {$[17],[20]$} \\
\hline SOA & Service-oriented architecture and applications & {$[15]$} \\
\hline SocNet & Social networking and collaboration & {$[6]$} \\
\hline Virtual & Virtualization technology & \\
\hline & & \\
\hline
\end{tabular}

Frequency analysis can be used to conduct an evaluation of the courses and emerging trends examined in this study group. Here the frequency is used to indicate the occurrences for the courses and trends. The total frequency count provides a summary measure for these parameters. There are five key analytic formulas. The Deployment Index (DI) is the frequency of a course category within a school type or category. The Relational Index (RI) measures the relation of the individually observed courses with the course categories and the identified trend categories. The Trend Index (TI) enumerates the relationship of the courses with regard to the emerging trends. The Influence Index (II) quantifies the relationship of emerging trends with respect to the courses. That is, the TI and II are the summary column and row totals of the RI matrix measures, respectively. The Affinity Index (AI) is an overall impact parameter of the emerging trends related to the courses. The AI may use a weighting factor of two (2) to apply a priority to the courses of aspirational school versus the peer schools. That is, the aspirational schools are viewed to have a greater impact on the assessment as they represent the preferred direction for course development in order to move towards the reputations of these schools. Of course, for an individual evaluation, a different weighting factor may be used. This depends on the importance of an aspirational school versus a peer school. The formulas for this analysis are: 


\section{Issues in Information Systems}

Volume 13, Issue 2, pp. 238-247, 2012

(1) Deployment Index (DI)

$$
\begin{aligned}
& D I_{i, j}=\sum_{k} f_{i, j, k} \\
& \text { Where, } \\
& \begin{array}{l}
\mathrm{i}=\text { course category } \\
\mathrm{j}=\text { school category }(b, p, a) \\
k
\end{array}=\text { individual occurrence course and school categories }
\end{aligned}
$$

(2) Relational Index (RI)

$$
R I_{i, m}=\sum n f_{i, m, n}
$$

Where,

$$
\begin{aligned}
& \mathrm{i}=\text { course category } \\
& \mathrm{m}=\text { trend category } \\
& \mathrm{n}=\text { individual occurrence course and trend categories }
\end{aligned}
$$

(3) Trend Index (TI)

$$
\begin{aligned}
& \mathrm{TI}_{\mathrm{m}}=\sum_{\mathrm{i}} \mathrm{RI} \mathrm{i}, \mathrm{m} \\
& \text { Where, } \\
& \mathrm{i}=\text { course category } \\
& \mathrm{m}=\text { trend category }
\end{aligned}
$$

(4) Influence Index (II)

$$
\begin{aligned}
& \|_{i}=\sum_{m} R I_{i, m} \\
& \text { Where, } \\
& \quad \begin{array}{l}
i=\text { course category } \\
m=\text { trend category }
\end{array}
\end{aligned}
$$

(5) Affinity Index (AI)

$$
\begin{aligned}
& A I_{i}=I I_{i} *\left(\left(D I_{i, j=p}\right)+\left(2 * D I_{i, j=a}\right)\right) \\
& \text { Where, } \begin{aligned}
i=\text { course category } \\
j=\text { school category }(p, a) ;[p=\text { peer, a = aspirational }]
\end{aligned}
\end{aligned}
$$

The values for each of these indices can be calculated from the database table created for course and trend instances. The result is a major framework for guidance in course selections to support emerging trends.

\section{ANALYSIS}

This is an example application of the major framework which occurs within the degree framework. For data from a study group of schools and from emerging trends [4], the framework database is created (Table 3). 


\section{Issues in Information Systems}

Volume 13, Issue 2, pp. 238-247, 2012

Table 3 - Example Database Content for Analysis

\begin{tabular}{|c|c|c|c|c|c|}
\hline School & Number & Title & Required & $\begin{array}{l}\text { Course } \\
\text { Category }\end{array}$ & $\begin{array}{l}\text { Trend } \\
\text { Code }\end{array}$ \\
\hline $\mathrm{B}$ & BIS 423 & $\begin{array}{l}\text { Decision Support Systems \& Business } \\
\text { Intelligence }\end{array}$ & $\mathrm{y}$ & $\mathrm{BI}$ & BusInt \\
\hline B & BIS 228 & Application Development & $\mathrm{y}$ & $\mathrm{CP}$ & \\
\hline $\mathrm{B}$ & BIS 357 & ABAP Programming Fundamentals & $\mathrm{n}$ & ERP & ERP \\
\hline $\mathrm{B}$ & BIS 458 & SAP Configuration and Implementation & $\mathrm{n}$ & ERP & ERP \\
\hline $\mathrm{B}$ & BIS 327 & Web Site Development & $\mathrm{n}$ & WEB & SocNet \\
\hline $\mathrm{B}$ & BIS 380 & Business Compter Networking & $\mathrm{n}$ & NET & Comm \\
\hline $\mathrm{B}$ & BIS 422 & Database Management Systems & $\mathrm{y}$ & $\mathrm{DB}$ & Big Data \\
\hline $\mathrm{B}$ & BIS 425 & Information Systems Development Project & $\mathrm{y}$ & ISP & \\
\hline B & BIS 420 & System Analysis and Design & $\mathrm{y}$ & SAD & \\
\hline P1 & $\begin{array}{l}\text { MIS } \\
4400\end{array}$ & Database Management Systems & $\mathrm{y}$ & DB & Big Data \\
\hline $\mathrm{P} 1$ & $\begin{array}{l}\text { MIS } \\
4500\end{array}$ & Business Process Management with SAP & $\mathrm{y}$ & ERP & ERP \\
\hline P1 & $\begin{array}{l}\text { MIS } \\
4210\end{array}$ & Data Communications & $\mathrm{y}$ & NET & Comm \\
\hline P1 & $\begin{array}{l}\text { MIS } \\
4220\end{array}$ & IT Security & $\mathrm{n}$ & SEC & Security \\
\hline P1 & $\begin{array}{l}\text { MIS } \\
4720\end{array}$ & IS Project Management & $\mathrm{n}$ & PM & \\
\hline $\mathrm{P} 1$ & $\begin{array}{l}\text { MIS } \\
4710\end{array}$ & Systems Analysis and Design & $\mathrm{y}$ & SAD & \\
\hline $\mathrm{A} 1$ & MIS 387 & Designing Business Systems & $\mathrm{y}$ & SAD & \\
\hline A1 & MIS 245 & Database Systems and Data Warehousing & $\mathrm{y}$ & $\mathrm{DB}$ & Big Data \\
\hline A1 & MIS 404 & $\begin{array}{l}\text { Business Intelligence and Knowledge } \\
\text { Management }\end{array}$ & $\mathrm{y}$ & $\mathrm{BI}$ & BusInt \\
\hline A1 & MIS 281 & Building Web-Based Business Applications I & $\mathrm{y}$ & WEB & SocNet \\
\hline A1 & MIS 301 & Data Communications in Business & $\mathrm{y}$ & NET & Comm \\
\hline A1 & MIS 385 & $\begin{array}{l}\text { Applications of Electronic Commerce } \\
\text { Technology }\end{array}$ & $\mathrm{n}$ & EBUS & \\
\hline $\mathrm{A} 1$ & MIS 403 & $\begin{array}{l}\text { Building Web-Based Business Applications } \\
\text { II }\end{array}$ & $\mathrm{y}$ & WEB & SocNet \\
\hline $\mathrm{A} 1$ & MIS 406 & IT Project Management & $\mathrm{y}$ & PM & \\
\hline A1 & MIS 495 & Managing the Intelligent Enterprise & $\mathrm{n}$ & SSM & SOA \\
\hline
\end{tabular}

In Table 3, the Course Category contains the classification that emerged from judgment applied to all course among the study group schools. The Trend Code specifies an emerging trend that best aligns with the Course Category.

Results are explored using the five indices of DI, RI, TI, II, and AI to guide the selection of courses for the suggested revised IS major. Foundations courses may be determined from the DI indices, which are reinforced by the AI values. These courses are considered as required with all the IT trends and, hence, are necessary for any trend to occur. That is, the knowledge from these courses is needed before students can apply knowledge in the application of emerging trends within a business organization. 


\section{Issues in Information Systems}

Volume 13, Issue 2, pp. 238-247, 2012

The DI values for the required courses are likely to suggest a strong consensus for the three courses of CP, DB, and SAD. However, this relationship should surface from the data of the study group schools. On the other hand, the DI values for the elective courses are likely to show a large number of different views on important topics for the IS major. For example, it is expected that BI and SEC may surface here as more frequently occurring courses. If this result appears, it will be driven by the data analysis.

The RI matrix (Table 4) demonstrates the mapping among the course categories and the trend categories of this study. The table indicates the frequency of occurrence of confluence of the Course Categories and the Emerging Trends. Those with the highest values should be considered as primary candidate course for making revision to the IS Major.

Table 4 - Example Relational Index (RI) Matrix

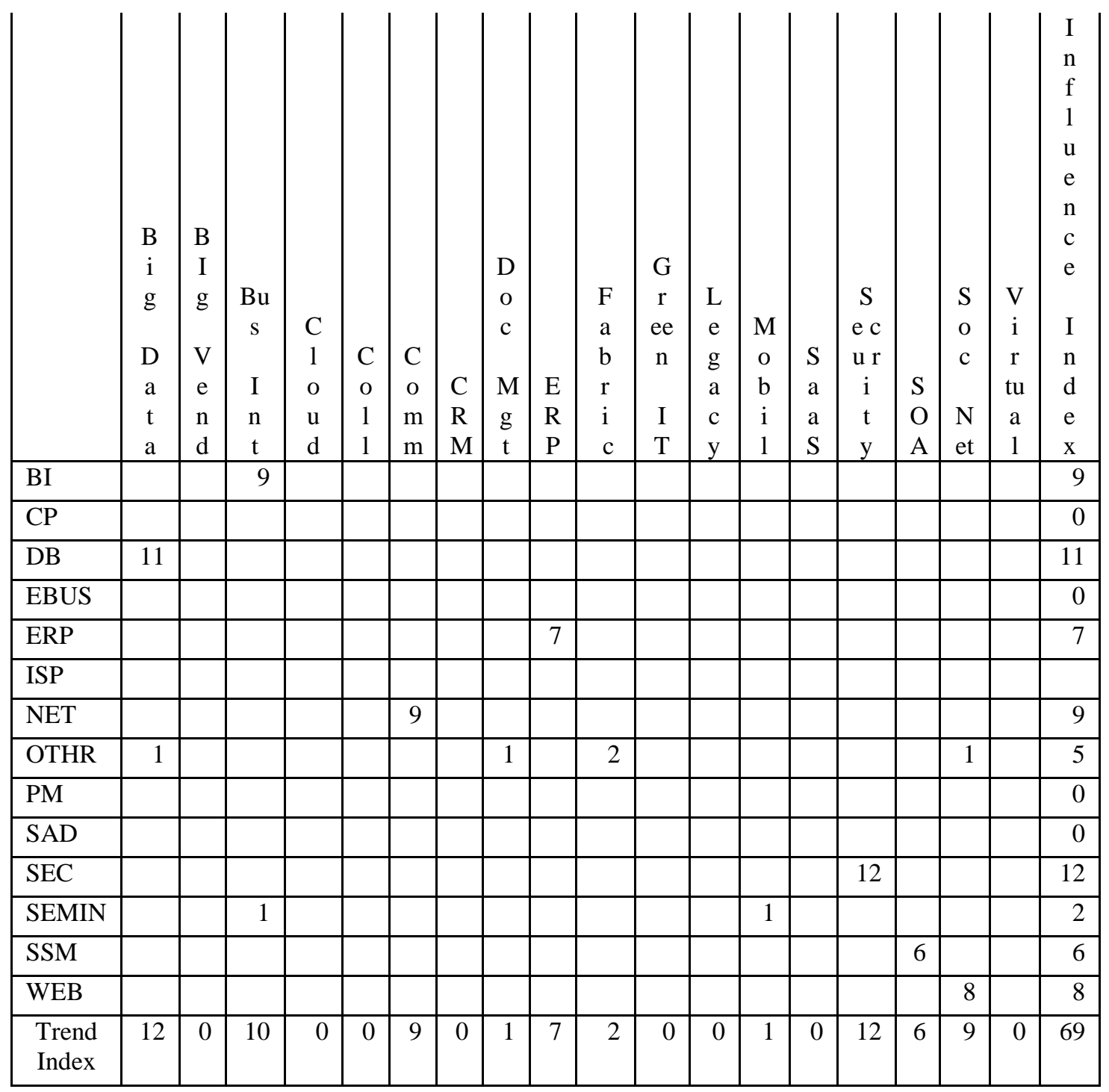

\section{DISCUSSION}

Considering the example results (Table 4), the analysis yields a group of nine course subjects for potential inclusion in an updated IS major. For that analysis, the CP and SAD courses appear with AI values of zeros indicating there is no emerging trend that is directly related to the subjects of those courses. However, the DI 


\section{Issues in Information Systems}

Volume 13, Issue 2, pp. 238-247, 2012

values are likely to suggest these are important courses among all study group schools would be evidenced by the DI values from data in a Courses by Category analysis. This is expected to occur because they are foundational courses for which knowledge is required by all IS majors. The explanation is this knowledge is expected to support the understanding of emerging IS trends. Because of this foundational expectation, they would be included in the required courses for the IS major (DI values). These results should be corroborated by the research of Lee and Mirchandani [12] and support the analytic framework method of this inquiry. The DB course is similar to the $\mathrm{CP}$ and SAD as a foundational course. However, it is likely to be supported by its AI value, because DB is related to the Big Data trend. That is, Big Data is operationalized by it deployment in the DB course types. Moreover, this suggests the use of a blended framework implementation, whereby the DB course may have the Big Data trend included in its course content. And, this is likely to transpire in a similar manner for other courses that have a match with a trend category.

Balancing the foundational courses of $\mathrm{CP}, \mathrm{SAD}$, and $\mathrm{DB}$ with the courses derived from the AI values and mapped to emerging trends, then the recommend course categories for a suggested revised IS major can be ascertained.

\section{SUMMARY AND CONCLUSION}

This inquiry has presented a two-part framework of the BB degree and the IS major, that lives within that degree. The IS major framework poses three approaches - (1) augmented, (2) integrated, and (3) blended. That framework considers how emerging technology may be integrated into the IS major of the BB degree. These are not mutually exclusive, but rather provide a conceptual context for this integration. The IS major framework poses five indexes for examining the individual course content within the IS major. These indexes employ a data-driven approach to decision making. In this manner, a "recommended" set of IS major courses is proposed based on the confluence of IS major courses and emerging IT trends. From that set of courses and trends, an individual school may assess and revise its IS major. Future work should apply data from a study group of schools to determine a proposed set of course for an IS major that incorporate many of the currently emerging trends. And, as some trends have a shorter life span than others, other future research could consider weighting factors for Trend categories, such as the number of years as a top trend, recruitment weights, and significance to the discipline. Rarely can a curriculum include all important trends. Some trends have more future impact on the IS/IT discipline than others. This reinforces the need for ongoing investigation of IS curriculum and the impact of trends upon it.

\section{REFERENCES}

[1] Bowers, T.. (2011, October). Tech trends for 2012: where career potential lies. TechRepublic. Retrieve November 11, 2011 from http://www.techrepublic.com/blog/career/tech-trends-for-2012-where-careerpotential-lies/3562?tag=content;siu-container.

[2] Computer Economics. (2011). Technology trends 2011/2012. Irvine, CA: Computer Economics, Inc.

[3] Costello, T.. (2011). 2011 IT Tech and Strategy Trends. IT Professional Magazine, 13(1), 61-65. Retrieved November 17, 2011, from ABI/INFORM Global. (Document ID: 2253333211).

[4] Hayen, R.. (2011). [Trends in IS majors]. Raw research data.

[5] Hiner, J.. (2011, October). Look out: the 10 rising tech trends of 2010. TechRepublic.

[6] Hurlburt, G., \& Voas, J.. (2011). The Evolution of Ubiquitously Intelligent Computing. IT Professional Magazine, 13(4), 56-60. Retrieved November 14, 2011, from ABI/INFORM Global. (Document ID: 2403526711).

[7] Hurlburt, G., Voas, J., \& W Miller, K.. (2010). Mobile Applications: The Fifth Cycle. IT Professional Magazine, 12(6), 56-60. Retrieved November 14, 2011, from ABI/INFORM Global. (Document ID: 2205359411). 


\section{Issues in Information Systems}

Volume 13, Issue 2, pp. 238-247, 2012

[8] Jepsen, T., Mithas, S., Hsu, C., \& Kraft, G.. (2010). Healthcare IT. IT Professional Magazine, 12(2), 14-16. Retrieved November 11, 2011, from ABI/INFORM Global. (Document ID: 1993753731).

[9] Kirkpatrick, G.. (2011, February). 10 tech trends to watch. TechRepublic. Retrieved November 11, 2011 from http://i.techrepublic.com.com/downloads/Gilbert/adl_10_trends2011.pdf.

[10] Kuhn, R., \& Johnson, C.. (2010). Vulnerability Trends: Measuring Progress. IT Professional Magazine, 12(4), 51-53. Retrieved November 19, 2011, from ABI/INFORM Global. (Document ID: 2081450391).

[11] Laplante, P.. (2010). IT Predictions, 2010. IT Professional Magazine, 12(1), 53-56. Retrieved November 19, 2011, from ABI/INFORM Global. (Document ID: 1950119781).

[12] Lee, K., \& Mirchandani, D.. (2010). DYNAMICS OF THE IMPORTANCE OF IS/IT SKILLS. The Journal of Computer Information Systems, 50(4), 67-78. Retrieved November 14, 2011, from ABI/INFORM Global. (Document ID: 2125384411).

[13] Lin, G., Fu, D., Zhu, J., \& Dasmalchi, G.. (2009). Cloud Computing: IT as a Service. IT Professional Magazine, 11(2), 10-13. Retrieved November 16, 2011, from ABI/INFORM Global. (Document ID: $1662687131)$.

[14] Liu, S., \& Cheng, B.. (2009). Cyberattacks: Why, What, Who, and How. IT Professional Magazine, 11(3), 14-21. Retrieved November 15, 2011, from ABI/INFORM Global. (Document ID: 1723757191).

[15] Liu, Q., \& Stallaert, J.. (2010). Is Your Enterprise Warming Up to Carbon 2.0? IT Professional Magazine, 12(5), 48-57. Retrieved November 14, 2011, from ABI/INFORM Global. (Document ID: 2149253251).

[16] Luo, Y.. (2010). Network I/O Virtualization for Cloud Computing. IT Professional Magazine, 12(5), 36-41. Retrieved November 16, 2011, from ABI/INFORM Global. (Document ID: 2149253211).

[17] Ortega, B.. (2009, March). Visual basic and C\# programming languages to converge. IT Professional, p.6.

[18] Paquet, R.. (2011, March). Technology trends you can't afford to ignore. Stamford, CT: Gartner, Inc.

[19] Pierson, J., Kruck, S., \& Teer, F.. (2008). TRENDS IN NAMES OF UNDERGRADUATE COMPUTERRELATED MAJORS IN AACSB-ACCREDITED SCHOOLS OF BUSINESS IN THE USA. The Journal of Computer Information Systems, 49(2), 26-31. Retrieved November 14, 2011, from ABI/INFORM Global. (Document ID: 1641412771).

[20] Sahoo, M.. (2009). IT Innovations: Evaluate, Strategize, and Invest. IT Professional Magazine, 11(6), 1622. Retrieved November 14, 2011, from ABI/INFORM Global. (Document ID: 1902922921).

[21] Stevens, D., Totaro, M., \& Zhu, Z.. (2011). ASSESSING IT CRITICAL SKILLS AND REVISING THE MIS CURRICULUM. The Journal of Computer Information Systems, 51(3), 85-95. Retrieved November 19, 2011, from ABI/INFORM Global. (Document ID:

[22] Unhelkar, B. (2011). Green IT: The Next Five Years. IT Professional Magazine, 13(2), 56-59. Retrieved November 17, 2011, from ABI/INFORM Global. (Document ID: 2296276131). 